\title{
PENCIRIAN DAN UJI AKTIVITAS KATALITIK ZEOLIT ALAM TERAKTIVASI
}

\author{
Charlena, Henny Purwaningsih dan Tina Rosdiana \\ Departemen Kimia, Institut Pertanian Bogor
}

\begin{abstract}
Natural zeolite reserves are spread in Indonesia, but they are not yet used optimally. Generally, natural zeolite have poor crystalline, various pore size, low catalytic activity, and high contaminant. Natural zeolite need to be activated and modified before it can be used. The objectives of this research were to activite the natural zeolite that already got acid and thermal treatments and to characterize it and catalytic activity was tested in interesterification reaction. Fourier transformation infrared (FTIR) spectra showed that the structure of natural zeolite activated by acid and thermal (NZAT) treatments were damaged. While, natural zeolite structure activated with acid (natural zeolite acid /NZA) did not show significant different to natural zeolite (NZ). Result of Si/Al ratio analysis showed that $\mathrm{Si} / \mathrm{Al}$ ratio NZA higer than $\mathrm{Si} / \mathrm{Al}$ ratio NZAT. The result of cation analysis by atomic absorption spectroscopy shoed that the general content of $\mathrm{Na}, \mathrm{K}, \mathrm{Fe}$ and $\mathrm{Ca}$ in the catalyst decreased because of acid and thermal treatments. Surface area and pore volume increased by the treatments. Catalytic activity of NZA in interesterification reaction gave a white cork product and in yield $35.78 \%$.
\end{abstract}

Keywords : natural zeolite activated, catalytic activity, FTIR.

\section{PENDAHULUAN}

Indonesia merupakan salah satu negara yang kaya akan zeolit alam, yang tersebar luas di berbagai lokasi antara lain di Bayah (Banten Selatan), Cikembar (Sukabumi), Nanggung (Tasikmalaya), Malang, Lampung, dan Sulawesi Selatan. Zeolit alam ini belum dimanfaatkan secara optimal. Upaya-upaya penelitian dan pengembangan berwawasan lingkungan terhadap sumber daya mineral tersebut perlu terus dilakukan sehingga dapat memberikan hasil yang nyata secara ekonomi ${ }^{[1]}$.

Zeolit alam terdiri atas gugus alumina oksida dan gugus silika oksida yang masing-masing berbentuk tetrahedral dan saling dihubungkan oleh atom oksigen sedemikian rupa sehingga membentuk kerangka tiga dimensi yang disebut struktur kerangka (framework) tiga dimensi. Sifat yang dimiliki oleh zeolit dimungkinkan untuk dimodifikasi menjadi katalis, adsorben, penukar ion, maupun sebagai pengemban logam aktif ${ }^{2]}$

Zeolit alam pada umumnya memiliki kristalinitas rendah, ukuran porinya tidak seragam, aktivitas katalitiknya rendah, dan mengandung banyak pengotor. Oleh karena itu perlu diaktivasi dan dimodifikasi terlebih dahulu sebelum dapat digunakan ${ }^{[3,4]}$.

Modifikasi zeolit alam dengan $\mathrm{HCl} 6 \mathrm{~N}$ pernah dilakukan ${ }^{[5]}$. Zeolit alam setelah mendapatkan perlakuan mengalami perubahan struktur dan komposisi. Adapun modifikasi dengan pemanasan pada suhu $540{ }^{\circ} \mathrm{C}$ yang ditujukan untuk membantu proses impregnasi terhadap zeolit sintetis H-ZSM5 juga sudah diteliti ${ }^{[6]}$.

Penelitian ini bertujuan mengaktivasi zeolit alam dengan $\mathrm{H}_{2} \mathrm{SO}_{4}$, melakukan pencirian terhadap zeolit alam yang sudah diaktivasi, dan menguji aktivitas katalitiknya pada reaksi interesterifikasi. Aktivasi dalam penelitian dilakukan dengan dua cara, yaitu perlakuan dengan asam tanpa pemanasan (nature zeolit acid/NZA) dan perlakuan asam yang dilanjutkan dengan pemanasan (nature zeolit acid and termal/NZAT).

Untuk melihat proses aktivitas katalis zeolit pada penelitian ini dilakukan sintesis ester glukosa miristat yang diperoleh dari reaksi 
antara metil miristat dan glukosa pentaasetat dengan metode bebas pelarut dengan katalis zeolit sintetik ${ }^{[7]}$.

Hipotesis penelitian ini adalah zeolit yang diaktivasi asam tanpa pemanasan maupun zeolit yang diaktivasi asam dengan pemanasan memiliki sifat-sifat zeolit (nisbah Si/Al, kandungan kation, dan sifat permukaan) lebih baik dibandingkan zeolit sebelum diaktivasi.

Hasil penelitian ini diharapkan dapat memberikan informasi zeolit hasil aktivasi tersebut dapat digunakan sebagai katalis dengan aktivitas katalitik yang baik.

\section{METODOLOGI}

\section{Alat dan Bahan}

Alat-alat yang digunakan dalam penelitian ini adalah gelas piala $(50,100$, dan $500 \mathrm{~mL})$, labu ukur $(25,50,100$, dan $250 \mathrm{~mL})$, labu bulat, kondensor, penangas air, termometer, neraca analitik, tanur, oven pengering, kondensor, termometer, atomic absorption spectroscopy (AAS), autosorb quantrochome 6B, spektrofotometer fourier transform infrared (FTIR) merek bruker jenis tentor 37, dan alatalat kaca lainnya.

Bahan utama yang digunakan adalah zeolit alam ukuran 60 mesh dari Pusat Penelitian dan Pengembangan Teknologi Mineral Bandung, kertas saring, akuades, larutan $\mathrm{H}_{2} \mathrm{SO}_{4} 0,2 \mathrm{~N}$, larutan $\mathrm{NH}_{4} \mathrm{NO}_{3} 0,1 \mathrm{M}$, metil miristat, glukosa pentaasetat, etanol 30-40\%, $\mathrm{NaHCO}_{3}, \mathrm{pH}$ universal dan larutan akuaregia.

\section{Prosedur}

\section{Preparasi Zeolit}

Sampel diambil dari Pusat Penelitian dan Pengembangan Teknologi Mineral (P3TM) Bandung. Zeolit berasal dari daerah Cikotok. Pengayakan dan penggilingan sampel zeolit dilakukan untuk memperoleh partikel-partikel yang berukuran 60 mesh karena pada ukuran ini zeolit cukup optimal dalam aktivitasnya.

Penentuan Kadar Air Zeolit Alam
Cawan petri yang telah disiapkan dikeringkan dalam oven dan diketahui bobot kosongnya. Cawan petri yang berisi sampel dikeringkan dalam oven pada suhu $105^{\circ} \mathrm{C}$ selanjutnya didinginkan. Setelah dingin disimpan dalam desikator lalu ditimbang. Pengeringan dilakukan beberapa kali selama 3 jam sampai diperoleh bobot tetap.

$$
\text { Kadar Air }=\frac{\mathrm{A}-\mathrm{B}}{\mathrm{C}} \times 100 \%
$$

$$
\begin{aligned}
& \mathrm{A}=\begin{array}{l}
\text { bobot sampel } \\
\text { dikeringkan }
\end{array} \\
& \mathrm{B}=\begin{array}{l}
\text { bobot sampel } \\
\text { dikeringkan }
\end{array} \\
& \mathrm{C}=\text { cawan sebelum } \\
& \text { bobot sampel }
\end{aligned}
$$

\section{Preparasi Katalis Zeolit Alam (NZ)}

Zeolit alam dari P3TM yang telah dihaluskan dengan ukuran 60 mesh direndam dalam akuades sambil diaduk dengan pengaduk besi (sudip) selama 1 jam pada suhu kamar, kemudian disaring dan dikeringkan dalam oven pada $120^{\circ} \mathrm{C}$ sampai kering.

\section{Preparasi Katalis Zeolit Alam Perlakuan Asam $^{[8]}$}

Sampel zeolit alam (NZ) direfluks selama 1 jam dengan larutan asam sulfat $0,2 \mathrm{~N}$ pada suhu $90^{\circ} \mathrm{C}$ sambil diaduk. Selanjutnya sampel disaring dan dicuci dengan akuades sampai $\mathrm{pH}=6$. Berikutnya sampel dikeringkan dan dihaluskan sehingga diperoleh katalis zeolit alam yang diaktivasi asam (NZA).

\section{Preparasi Katalis Zeolit Alam Perlakuan Pemanasan $^{[6]}$}

Sampel NZA dikeringkan dalam tanur $540^{\circ} \mathrm{C}$ selama 12 jam, selanjutnya sampel direndam dalam larutan $\mathrm{NH}_{4} \mathrm{NO}_{3} 0,1 \mathrm{M}$ selama 2 jam sebanyak tiga kali ulangan. Kemudian sampel NZA tersebut dipanaskan pada suhu $120^{\circ} \mathrm{C}$ selama 24 jam dan dilanjutkan dengan pemanasan pada suhu $540^{\circ} \mathrm{C}$ selama 4 jam sehingga diperoleh zeolit alam yang diaktivasi asam dan pemanasan (NZAT).

Penentuan Kandungan Kation Logam ( $\mathrm{Na}, \mathrm{Ca}$, $K$, dan $\mathrm{Fe}$ ) 
Penentuan kandungan kation logam dalam katalis NZ, NZA, dan NZAT dilakukan dengan cara destruksi (dalam lemari asam). Hal ini dilakukan berkaitan dengan sifat kation dalam zeolit yang berperan sebagai pengontrol aktivitas katalisis. Sampel zeolit sebanyak 0,2 $\mathrm{g}$ ditempatkan dalam cawan porselin ditambahkan $2 \mathrm{~mL}$ akuaregia $\left(\mathrm{HNO}_{3}\right.$ pa: $\mathrm{HCl}$ $\mathrm{pa}=1: 3$ ) kemudian dipanaskan selama 30 menit. Setelah lima menit ke dalam campuran ditambahkan $\mathrm{H}_{2} \mathrm{SO}_{4} 4 \%$ sebanyak $0,5 \mathrm{~mL}$ dan dipanaskan selama 15 menit, kemudian ditambahkan $1 \mathrm{~mL}$ akuaregia dan $\mathrm{H}_{2} \mathrm{SO}_{4} 4 \%$ sebanyak $0,25 \mathrm{~mL}$ dan dibiarkan selama 10 menit. Campuran diencerkan ke dalam labu ukur $25 \mathrm{~mL}$ hingga tera, sehingga diperoleh larutan sampel zeolit alam (NZ), zeolit alam yang diaktivasi asam (NZA), dan zeolit alam yang diaktivasi asam dan pemanasan (NZAT) masing-masing sebesar $0,2 \mathrm{~g} / 25 \mathrm{~mL}$ atau 8000 ppm. Selanjutnya masing-masing contoh zeolit tersebut ditentukan kandungan kation logamnya (Na, $\mathrm{Ca}, \mathrm{K}, \mathrm{Fe})$ dengan AAS.

\section{Analisis FTIR}

Sampel sebanyak $0,1 \mathrm{~g}$ yang telah dikeringkan pada $120^{\circ} \mathrm{C}$ selama 3 jam digerus dengan padatan $\mathrm{KBr}$ sebanyak $\pm 160 \mathrm{mg}$ lalu ditekan pada keadaan vakum hingga diperoleh lempeng tipis yang transparan. Pengukuran dilakukan pada daerah IR tengah, yaitu pada bilangan gelombang $400-4000 \mathrm{~cm}^{-1}$.

\section{Penentuan Nisbah Si/Al dengan Metode Baseline}

Suatu garis dasar (baseline) dibuat pada kedua lembah puncak lalu dihubungkan dengan menarik garis dari ujung puncak yang tegak lurus terhadap garis dasar. Selanjutnya tinggi puncak dihitung dari ujung puncak ke titik perpotongan garis dasar dengan garis yang tegak lurus terhadap garis dasar. Selanjutnya diukur nisbah Si/Al dengan metode garis dasar pada spektrum FTIR tersebut. Pertama-tama puncak tertinggi dicatat dan diukur garis dasar yang dipilih. Kemudian besar transmitan pada bilangan gelombang $1647 \mathrm{~cm}^{-1}$ (serapan gugus Si-O) dengan transmitan pada bilangan gelombang $1045 \mathrm{~cm}^{-1}$ (serapan Al-O) maka nisbah dapat diperoleh dari hasil perbandingan tersebut.
Penentuan Luas Permukaan Spesifik, Volume Total Pori, dan Rerata Jejari Pori

Luas permukaan spesifik, volume total pori, dan rerata jejari pori didasarkan pada fenomena adsorpsi gas lapis tunggal yang berlangsung pada suhu konstan. Alat yang digunakan adalah autosorb quantrochome $6 B$ yang berada di Departemen Teknik Gas dan Petrokimia, Fakultas Teknik, Universitas Indonesia, Depok.

Sampel zeolit ditimbang dan dimasukkan dalam wadah sampel dan dipanaskan pada suhu $200^{\circ} \mathrm{C}$, selanjutnya dilakukan pengusiran gas menggunakan gas nitrogen selama 45 menit. Kemudian sampel didinginkan dengan nitrogen cair sehingga suhu contoh mencapai $77^{\circ} \mathrm{K}$. Tekanan gas nitrogen diubah sehingga jumlah gas nitrogen yang terkondensasi dapat ditentukan. Dengan diperolehnya data tersebut, maka luas permukaan spesifik, volume total pori, dan rerata jari pori dapat ditentukan.

\section{Sintesis Ester Glukosa Miristat ${ }^{[7]}$}

Sintesis ester glukosa miristat dilakukan dengan nisbah miristat dan GPA 1:1, serta zeolit sebesar $10 \%$ dari total reaktan. Sintesis ini dimulai dengan mencampurkan metil miristat, GPA, dan zeolit yang dimasukkan ke dalam labu bulat yang dilengkapi pendingin dan pengaduk magnetik, kemudian dipanaskan pada suhu $90^{\circ} \mathrm{C}$ dalam penangas air mendidih selama 6 jam.

\section{Pemisahan Ester Glukosa Miristat ${ }^{[9]}$}

Campuran homogen yang terbentuk dari hasil sintesis ditambahkan dengan larutan etanol hangat dan dinetralkan dengan beberapa tetes larutan $\mathrm{NaHCO}_{3} 1 \mathrm{M}$ kemudian disaring dalam kondisi hangat sampai dihasilkan endapan A dan filtrat. Filtrat yang berisi pelarut etanol diuapkan sehingga dihasilkan endapan A dan B (residu) ditambahkan heksana lalu diuapkan sampai didapatkan miristat yang tidak bereaksi. Kemudian masing-masing endapan ditambahkan etanol hangat dan didinginkan pada suhu $-4{ }^{\circ} \mathrm{C}$ sampai $0{ }^{\circ} \mathrm{C}$ hingga terdapat endapan putih. Campuran tersebut disaring, endapan yang diperoleh adalah GPA yang tidak bereaksi dan katalis zeolit sedangkan 
filtratnya berisi ester glukosa asam lemak. Pelarut etanol pada filtrat dapat dihilangkan dengan cara diuapkan sampai terbentuk padatan ester glukosa miristat. Selanjutnya produk ditentukan persentase hasil.

\section{HASIL DAN PEMBAHASAN}

\section{Aktivasi Zeolit}

Kadar air zeolit alam sebelum aktivasi diukur dengan metode gravimetri, hasilnya diperoleh kadar air zeolit alam sebesar 4,01\%. Nilai kadar air ini menunjukkan proporsi volume pori yang dihuni oleh molekul air. Semakin rendah kadar air produk zeolit semakin tinggi mutunya. Untuk nilai tersebut diusulkan tidak melebihi $5 \%{ }^{[10]}$.

Proses aktivasi zeolit alam dilakukan dengan dua cara, yaitu perlakuan asam tanpa pemanasan dan perlakuan asam yang dilanjutkan dengan pemanasan. Pada perlakuan asam zeolit direfluks selama 1,5 jam dalam $250 \mathrm{~mL}$ asam sulfat $0,2 \mathrm{~N}$. Aktivasi tersebut bertujuan membersihkan permukaan pori, membuang senyawa pengotor, dan mengatur kembali letak atom yang dapat dipertukarkan. Zeolit alam sebelum diaktivasi berwarna hijau, sedangkan zeolit teraktivasi asam berwarna hijau keabu-abuan.

Asam sulfat dipilih sebagai perefluks karena larutan asam sulfat dapat mengekstraksi Al dalam zeolit, yaitu Al dalam kerangka zeolit menjadi Al di luar kerangka zeolit yang disebut sebagai proses dealuminasi. Contoh reaksi pelepasan $\mathrm{Al}$ dari dalam kerangka zeolit oleh pelarut $\mathrm{HCl}$ dapat dilihat pada Gambar 1.

Cara aktivasi yang kedua adalah memberi perlakuan pemanasan pada zeolit alam yang sudah diaktivasi dengan $\mathrm{H}_{2} \mathrm{SO}_{4}$ pada suhu $540^{\circ} \mathrm{C}$ dilanjutkan dengan perendaman dalam $\mathrm{NH}_{4} \mathrm{NO}_{3} \quad 0,1 \quad \mathrm{M}$ sebanyak 3 kali ulangan. Garam $\mathrm{NH}_{4} \mathrm{NO}_{3}$ adalah penukar kation. Penambahan garam $\mathrm{NH}_{4} \mathrm{NO}_{3}$ bertujuan untuk mengaktifkan zeolit secara kimia yang dilakukan sebagai penukar kation, sehingga dalam proses pertukaran ion, ion dapat disubtitusi dengan kation $\mathrm{NH}_{4}{ }^{+}$yang ada pada permukaan zeolit. Selama pemanasan pada suhu $540^{\circ} \mathrm{C}$ dihasilkan zeolit yang berwarna jingga/oranye. Hal ini dikarenakan zeolit mengalami perubahan struktur akibat pemanasan yang terlalu tinggi.

\section{Analisis FTIR}

Pada Tabel 1 dapat dilihat perbandingan hasil spektrum FTIR katalis NZ, NZA, dan NZAT dengan spektrum FTIR dari zeolit alam bayah $^{[11]}$ yang menunjukkan serapan terjadi pada bilangan gelombang $3841 \mathrm{~cm}^{-1} ; 3448,5$ $\mathrm{cm}^{-1} ; 3822,7 \mathrm{~cm}^{-1} ; 3807,2 \mathrm{~cm}^{-1}$ (gugus $\mathrm{OH}$ ulur dari air yang terserap); $2376,1 \mathrm{~cm}^{-1}$ (gugus Si$\mathrm{OH}$ ); 1639,4 $\mathrm{cm}^{-1}$ (gugus Si-O), dan 1041,5 $\mathrm{cm}^{-1}$ (gugus Al-O).

Spektrum FTIR zeolit alam (NZ) dapat dilihat pada Gambar 2. Spektrum FTIR NZ menunjukkan puncak lebar pada $3624,47 \mathrm{~cm}^{-1}$ dan $3451,15 \mathrm{~cm}^{-1}$ berkaitan dengan adanya vibrasi $\mathrm{OH}$ ulur walau terlihat belum tajam. Pada daerah 400-1600 $\mathrm{cm}^{-1}$ terlihat bahwa puncak-puncak sudah terlihat tajam antara lain daerah serapan $1643 \mathrm{~cm}^{-1}$ adanya vibrasi $\mathrm{Si}-\mathrm{O}$, dan daerah $1045 \mathrm{~cm}^{-1}$ adanya vibrasi Al-O.

Gambar 3 menunjukkan spektrum NZA. Puncak-puncak terlihat jelas, yaitu pada 1046 $\mathrm{cm}^{-1}$ (gugus Al-O) yang lebih melebar dibandingkan NZ, bahu sekitar $1200 \mathrm{~cm}^{-1}$ (uluran asimetris), puncak $3626 \mathrm{~cm}^{-1}$ (gugus $\mathrm{OH})$ yang lebih sempit dibandingkan NZ, dan puncak pada $792 \mathrm{~cm}^{-1}$ semakin tajam dibandingkan dengan NZ.

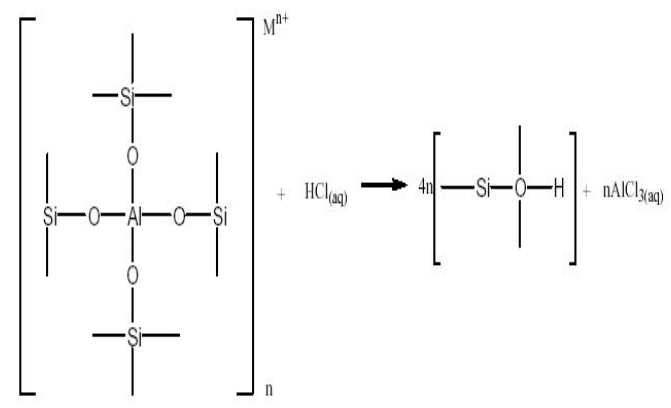

Gambar 1. Contoh reaksi pelepasan $\mathrm{Al}$ dari dalam kerangka zeolit 
dengan Zeolit Alam Bayah [11]

\begin{tabular}{lcccc}
\hline \multirow{2}{*}{ Jenis gugus } & \multicolumn{3}{c}{ Bilangan Gelombang $\left(\mathrm{cm}^{-1}\right)$} & \\
\cline { 2 - 4 } & katalis NZ & Katalis NZA & Katalis NZAT & $\begin{array}{c}\text { Zeolit } \\
\text { alam }\end{array}$ \\
\hline Gugus OH & 3624.47 & 3626.44 & tidak muncul & 3841.9 \\
& 3451.15 & 3451.52 & & 3822.7 \\
& & & & 3807.2 \\
& & & & 3448.5 \\
Gugus Si-OH & Tidak & & Tidak muncul & 2376.1 \\
Gugus Si-O & 1643.02 & 1642.63 & tidak muncul & 1639.4 \\
Gugus Al-O & 1045.88 & 1046.82 & 1087.13 & 1041.5 \\
Gugus K-O & 794.6 & 792.3 & 789.34 & 794.6 \\
Gugus Na-O & 465.01 & 465.13 & 470.75 & 624.9 \\
\hline
\end{tabular}

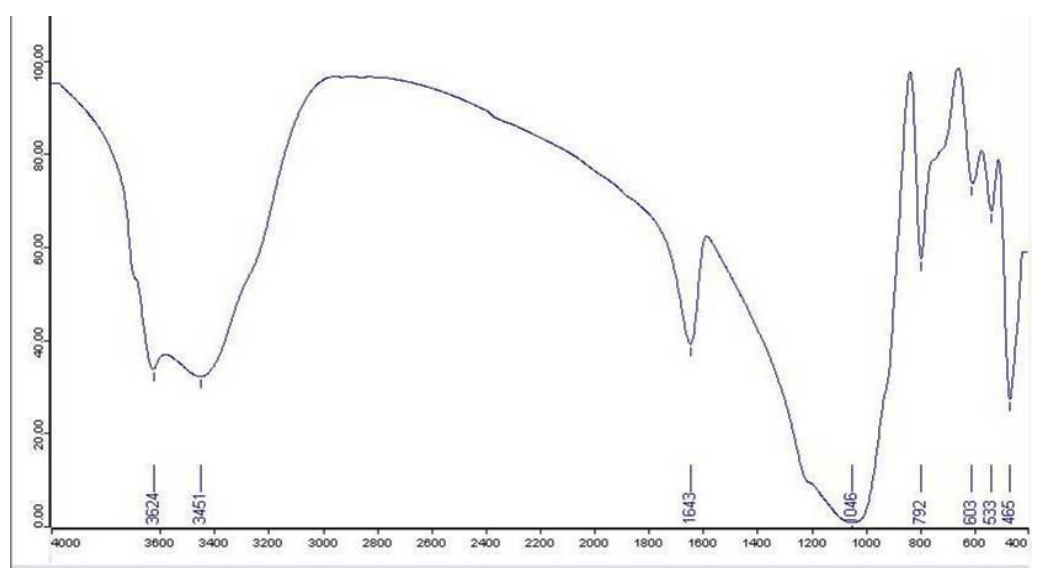

Gambar 2. Spektrum FTIR zeolit alam (NZ)

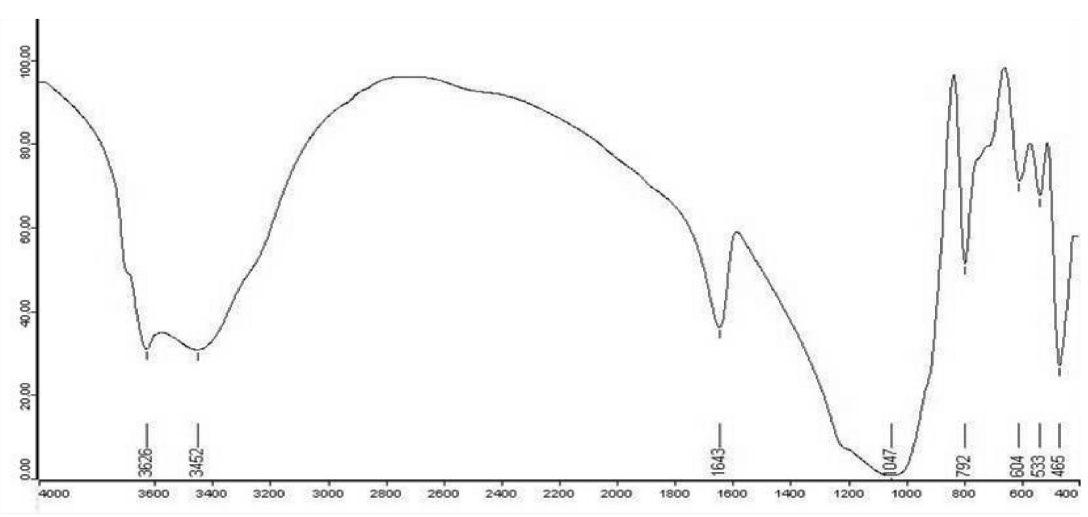

Gambar 3. Spektrum FTIR zeolit alam yang diaktivasi asam (NZA) 


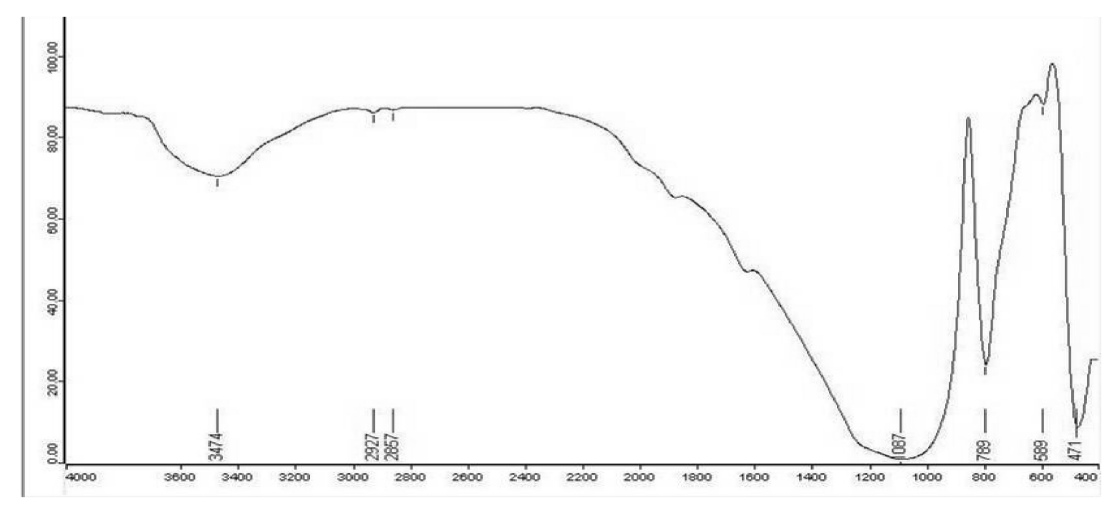

Gambar 4.. Spektrum FTIR zeolit alam yang diaktivasi asam dan pemanasan (NZAT)

Spektrum FTIR NZAT dapat dilihat pada Gambar 3. Adanya perubahan pada daerah vibrasi $\mathrm{OH}$ ulur dan Si-O ulur. Kedua puncak tidak muncul pada spektrum FTIR NZAT. Hal ini menunjukkan adanya kerusakan struktur zeolit. Kerusakan pada struktur zeolit diduga karena suhu yang digunakan pada perlakuan pemanasan terlalu tinggi. Pada sampel NZAT, spektrum FTIR juga tidak menunjukkan adanya vibrasi $\mathrm{OH}$ pada daerah selebar 3500$3700 \mathrm{~cm}^{-1}$ karena tertutup oleh vibrasi $-\mathrm{OH}$ yang lebar.

\section{Analisis Nisbah Si/Al}

Nisbah Si/Al menunjukkan besarnya muatan negatif zeolit, semakin besar jumlah Al yang dapat menggantikan $\mathrm{Si}$, maka semakin kecil nilai $\mathrm{Si} / \mathrm{Al}$ dan semakin besar muatan negatif zeolit. Semakin banyak komposisi Al yang dapat dipertukarkan dalam zeolit, maka kualitas zeolit untuk pertukaran kation semakin baik. Kapasitas tukar kation zeolit tersebut semakin besar jika $\mathrm{Si} / \mathrm{Al}$ kecil yang berarti muatan negatif zeolit semakin besar ${ }^{[12]}$. Pada umumnya semakin besar nisbah $\mathrm{Si} / \mathrm{Al}$ besar dari suatu zeolit kapasitas zeolit sebagai penyerap semakin besar begitu pula dengan luas permukaan kontaknya.

Nisbah Si/Al yang diperoleh untuk NZ dan NZA masing-masing sebesar 0,4 dan 1 , untuk sampel NZAT nisbah Si/Al tidak dapat ditentukan. Hasil perhitungan nisbah ini dapat mengelompokkan zeolit NZA ini dalam jenis zeolit kadar Si rendah (kaya $\mathrm{Al}$ ), keadaan ini menyebabkan daya penukaran ion dari zeolit maksimum.
Aktivasi zeolit oleh asam sulfat menyebabkan terjadinya proses dealuminasi, yaitu proses keluarnya Al dari dalam kerangka zeolit menjadi Al di luar kerangka zeolit, sehingga Al dalam sampel NZA berkurang. Jumlah Al yang menurun berpengaruh terhadap nisbah $\mathrm{Si} / \mathrm{Al}$ pada sampel NZA, yaitu nisbah Si/Al semakin meningkat dibandingkan dengan nisbah $\mathrm{Si} / \mathrm{Al}$ pada zeolit alam murni (NZ).

Proses dealuminasi ini menurunkan kandungan $\mathrm{Al}$, sehingga jumlah $\mathrm{Al}$ yang dapat dipertukarkan dengan kation lain semakin rendah sehingga kapasitas tukar kation zeolit tersebut semakin kecil. Sampel zeolit yang diaktivasi asam dan pemanasan (NZAT) tidak dapat ditentukan nisbah $\mathrm{Si} / \mathrm{Al}$ melalui metode baseline karena puncak $\mathrm{Si}-\mathrm{O}$ tidak muncul. Hilangnya puncak Si-O diduga akibat rusaknya struktur zeolit karena pemanasan.

\section{Analisis AAS}

Penentuan kandungan kation dalam sampel katalis menggunakan alat atomic absorption spectrophotometry (AAS). Analisis ini berkaitan dengan peranan kation sebagai pengontrol aktivitas katalitik. Rongga molekul pada zeolit dapat dimasuki kation-kation $(\mathrm{Na}$, $\mathrm{K}$, $\mathrm{Ca}$, dan $\mathrm{Mg}$ ) yang dapat dipertukarkan sehingga mempengaruhi muatan negatif pada kerangka. Kandungan kation-kation dalam contoh katalis dapat dilihat dalam Gambar 5.

Gambar 5 menunjukkan kecenderungan logam kation dalam sampel katalis semakin menurun dengan adanya aktivasi zeolit yang meliputi pengasaman dan pemanasan terhadap zeolit. 


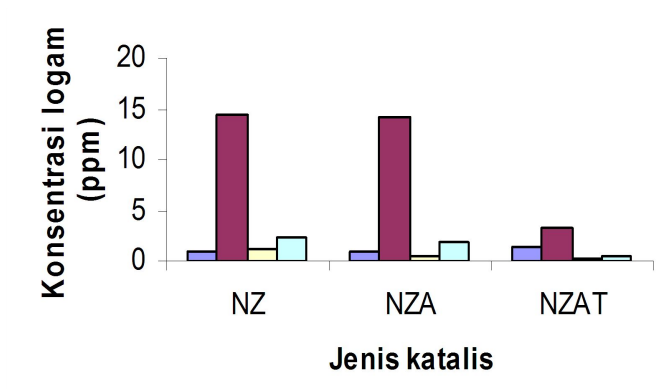

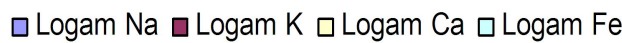

Gambar 5. Kandungan kation dalam sampel katalis

Akan tetapi kation logam $\mathrm{Na}$ mengalami peningkatan setelah mendapatkan perlakuan. Hal ini terjadi karena pada zeolit tersebut kemungkinan masih terdapat kontaminan dan preparasi larutan yang tidak cukup baik.

Pada umumnya kation dari logam alkali seperti $\mathrm{Na}$ dan $\mathrm{K}$ dapat menyebabkan deaktivasi terhadap contoh katalis. Deaktivasi terjadi karena pori-pori yang terblokade dan sisi aktif yang tertutupi ${ }^{[13]}$. Adanya logam $\mathrm{Na}$ dalam contoh katalis akan mengurangi pembentukan kokas (coke) dan gas serta dapat bersifat racun terhadap sampel katalis. Hasil pengamatan menunjukkan jumlah logam $\mathrm{Na}$ dan $\mathrm{K}$ sangat kecil sehingga pengaruh deaktivasi kedua logam ini sangat kecil. Kation logam K menunjukkan penurunan yang signifikan pada jenis zeolit NZAT.

Pada Gambar 5 dapat diamati jumlah logam kation $\mathrm{Ca}$ dan $\mathrm{Fe}$ yang menurun secara signifikan. Adanya kation divalen dan trivalen biasanya memberikan keaktifan pada katalis zeolit. Keaktifan disebabkan kation-kation tersebut dapat mengalami hidrolisis oleh adanya uap air untuk membentuk sisi asam Bronsted.

$$
\mathrm{M}^{\mathrm{n}+}+\mathrm{H}_{2} \mathrm{O} \longrightarrow \quad\left[\mathrm{MOH}^{](\mathrm{n}-1)+}+\mathrm{H}^{+}\right.
$$

Kation-kation dalam kerangka zeolit tersebut dapat ditukar dan disubtitusi tanpa mengubah struktur kerangka (isomorfis) yang dapat menimbulkan gradien medan elektronik dalam kanal-kanal dan ruangan zeolit.

Hasil penelitian menunjukkan kandungan logam $\mathrm{Na}, \mathrm{K}, \mathrm{Fe}$, dan $\mathrm{Ca}$ pada katalis zeolit semakin menurun dengan adanya perlakuan asam dan pemanasan. Pengasaman dan pemanasan menyebabkan proses dealuminasi yang menurunkan kandungan aluminium tempat terkaitnya logam-logam penetral muatan listrik pada zeolit. Kandungan aluminium yang menurun sebanding dengan penurunan kandungan logam penetral tersebut.

\section{Sifat Permukaan}

Penentuan sifat permukaan dilakukan dengan autosorb quantachrome $6 b$ menggunakan gas $\mathrm{N}_{2}$. Pada penentuan sifat permukaan tersebut, sampel padatan perlu dibebaskan dari kontaminan, misalnya air dan minyak. Proses ini dikenal dengan degassing. Degassing dilakukan dengan menempatkan contoh padat tersebut dalam sel gelas dan dipanaskan di bawah vakum dengan suhu konstan sebesar $200^{\circ} \mathrm{C}$. Histogram luas permukaan spesifik dari beberapa katalis disajikan pada Gambar 6 .

Luas permukaan spesifik (LPS) adalah luas permukaan tiap gram contoh katalis. Gambar 6 menunjukkan bahwa luas permukaan akan meningkat seiring dengan adanya perlakuan asam. Zeolit NZAT menunjukkan penurunan luas permukaan spesifik yang relatif besar. Peningkatan hanya terjadi pada perlakuan asam saja. Hal ini disebabkan terjadinya pembukaan pori zeolit alam yang semula tertutupi oleh pengotor melalui perlakuan dengan $\mathrm{H}_{2} \mathrm{SO}_{4}$. Dengan hilangnya pengotor organik dan anorganik yang berada pada padatan katalis akan menyebabkan menurunnya volume pori. Hal ini akan mengakibatkan peningkatan luas permukaan padatan.

Perlakuan pemanasan seharusnya menyebabkan peningkatan luas permukaan spesifik karena pemanasan zeolit dapat menguapkan air yang terperangkap dalam poripori kristal zeolit, sehingga luas permukaan pori-pori bertambah. Akan tetapi hal ini tidak terjadi karena kemungkinan distribusi pori zeolit yang kurang merata. Berkurangnya luas permukaan dapat disebabkan oleh distribusi pori yang kurang merata ${ }^{[14]}$.

\section{Volume Total Pori dan Rerata Jejari Pori}

Beberapa molekul dalam memasuki sistem mikropori zeolit akan ditahan berdasarkan kepolaran/efek interaksi lainnya dari molekul 
dengan zeolit. Sifat zeolit sebagai katalis yang penting adalah mempunyai ukuran pori yang besar dan "volume kosong tersedia" yang maksimum $^{[15]}$.

Gambar 7 dan 8 menunjukkan bahwa volume total pori meningkat setelah mendapatkan perlakuan asam. Hal ini terjadi karena poripori zeolit menjadi lebih terbuka dengan adanya pelarutan senyawa-senyawa pengotor yang menutupi pori sampel sebelumnya. Volume pori sampel NZAT lebih sedikit setelah mendapatkan perlakuan asam dan pemanasan. Sejalan dengan hasil analisis luas permukaan spesifiknya yang mengalami penurunan juga setelah mendapatkan perlakuan, maka kecilnya volume pori diduga karena terjadi pemanasan yang terlalu tinggi.

Gambar 8 menunjukkan bahwa rerata jari pori meningkat seiring dengan perlakuan aktivasi. Sampel zeolit yang diaktivasi asam mempunyai volume pori lebih besar sehingga jari-jari pori semakin kecil karena volume pori yang besar menunjukkan jumlah pori-pori yang dimiliki cukup banyak dan volume kosong yang tersedia minimum. Sebaliknya pada sampel zeolit yang diaktivasi asam dan pemanasan, volume pori menurun menunjukkan jari-jari pori yang ada besar dengan jumlah pori-pori sedikit sehingga volume kosong menjadi besar.

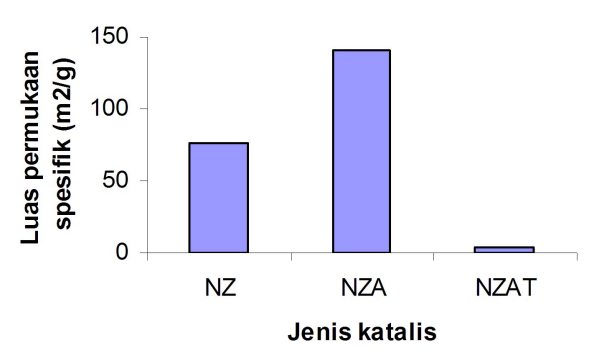

Gambar 6. Luas permukaan spesifik contoh katalis.

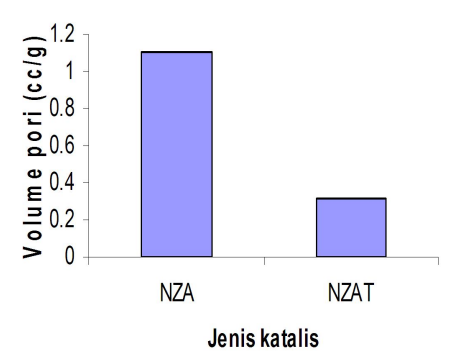

Gambar 7. Volume total pori contoh katalis

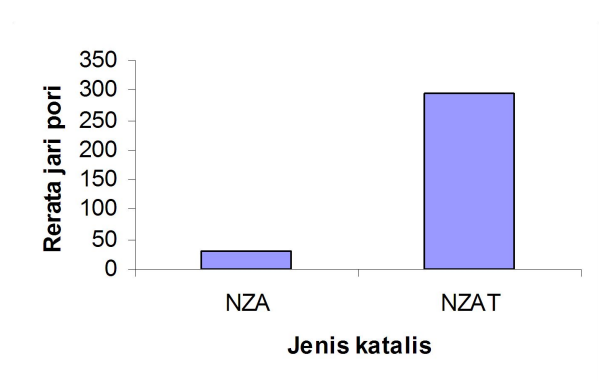

Gambar 8. Rerata jejari pori contoh katalis

\section{Reaksi Interesterifikasi}

Tahap akhir dalam penelitian ini adalah uji aktivitas katalitik katalis zeolit yang telah diaktivasi pada reaksi interesterifikasi metil miristat dan glukosapentaasetat.

Berdasarkan hasil pencirian yang telah dilakukan terhadap tiga katalis zeolit, maka katalis zeolit NZA dipilih untuk diuji aktivitas katalitiknya pada reaksi interesterifikasi. Interesterifikasi dalam penelitian ini dilakukan dengan perbandingan metil miristat dan GPA $1: 1$, serta zeolit alam asam (NZA) sebesar $10 \%$ dari total reaktan. Kondisi reaksi yang telah dilakukan pada suhu $90^{\circ} \mathrm{C}$ dalam labu bulat dengan pendingin dan kondensor tegak selama 6 jam $^{[7]}$. Produk yang terbentuk dari reaksi interesterifikasi tersebut adalah ester glukosa miristat. Total presentase hasil ester glikosa miristat yang diperolehnya adalah $87,27 \%$.

Pada penelitian ini total ester glukosa miristat yang diperoleh adalah 35,78\% atau lebih kecil dari total ester glukosa miristat ${ }^{[7]}$ dengan katalis zeolit sintetik. Perbedaan ini mungkin terjadi karena pemakaian jenis katalis zeolit yang berbeda, serta jumlah reaktan yang lebih kecil pada penelitian ini digunakan zeolit alam hasil aktivasi asam karena hasil pencirian menunjukkan zeolit ini lebih baik jika dilihat dari sifat permukaan, gugus yang dimiliki dan kandungan kationnya, sedangkan penelitian sebelumnya adalah zeolit sintetik. Zeolit sintetik memiliki kondisi yang lebih baik dalam mengkatalisis suatu reaksi karena struktur dan komposisi zeolit tersebut sesuai dengan kondisi yang diinginkan, misalnya dari nisbah $\mathrm{Si} / \mathrm{Al}$, luas permukaan spesifik dan volume pori. Hal ini menunjukkan sisi aktif zeolit alam asam lebih sedikit yang bereaksi dibandingkan zeolit sintetik sehingga produk yang dihasilkan lebih kecil, selain itu dapat 
terjadi karena penyaringan yang cepat sehingga filtrat belum terkumpul secara optimal. Senyawa ester glukosa miristat dihasilkan dengan tergantinya gugus asetil (dari unit GPA) dengan gugus alifatik (dari unit metil miristat). Hal ini menunjukkan puncak khas pada bilangan gelombang 2800$3000 \mathrm{~cm}^{-1}$ dengan adanya serapan vibrasi ulur $\mathrm{C}-\mathrm{H}$ pada $\mathrm{CH}_{3}-\mathrm{CH}_{2}$

\section{KESIMPULAN}

Proses aktivasi berpengaruh pada sifat-sifat permukaan zeolit alam. Aktivasi dengan perlakuan asam yang dilanjutkan dengan pemanasan pada suhu $540^{\circ} \mathrm{C}$ menyebabkan terjadinya perubahan struktur zeolit alam. Aktivasi dengan perlakuan asam tanpa pemanasan menyebabkan meningkatnya nisbah $\mathrm{Si} / \mathrm{Al}$, luas permukaan, dan volume total pori, sedangkan rerata jari porinya menurun. Kedua proses aktivasi menyebabkan penurunan kadar sebagian besar kation yang berpengaruh terhadap aktivitas katalitik. Katalis zeolit alam yang diaktivasi dengan perlakuan asam diuji aktivitas katalitiknya pada reaksi interesterifikasi. Rendemen produk yang dihasilkan adalah $35,78 \%$.

\section{DAFTAR PUSTAKA}

1. $[\mathrm{P} 3 \mathrm{TM}]$ Pusat Penelitian \& Pengembangan Teknologi Mineral, 1994 Cara Uji Pengukuran Luas Permukaan Spesifik Mineral Zeolit, Bandung: Pusat Penelitian \& Pengembangan Teknologi Mineral.

2. Othmer \& Kirk, 1995, Encyclopedia of Chemical Technology, Ed ke-4, New York: John Wiley.

3. Handoko, S. D., 2001, Aktivitas katalitik $\mathrm{Cr} /$ zeolit dalam reaksi konversi katalitik fenol dan metil isobutil keton [skripsi], Jember : Fakultas Matematika dan Ilmu Pengetahuan Alam, Universitas Jember.

4. Handoko, S. D., 2001, Preparasi katalis $\mathrm{Cr}$ /zeolit melalui modifikasi zeolit alam, [tesis], Jember : Fakultas Matematika dan Ilmu Pengetahuan Alam, Universitas Jember.

5. Jon, H., 2001, Pencirian zeolit alami termodifikasi asam, skripsi, Bogor :
Fakultas Matematika dan Ilmu Pengetahuan Alam, Institut Pertanian Bogor.

6. Shang, C. C., \& Lee, M. D., 1994, Effect of hydrogen pretreatment on the acidic and catalytic properties of galium-supported H-ZSM-5 in n-hexane aromatization, Applied Catalysis A. General, 123: 7-21.

7. Prihanjani, M., 2006, Sintesis ester glukosa miristat melalui interesterifikasi antara metil miristat dan glukosa pentaasetat. skripsi, Bogor: Fakultas Matematika dan Ilmu Pengetahuan Alam, Institut Pertanian Bogor.

8. Suyartono \& Husaini, 1991, Tinjauan Terhadap Kegiatan Penelitian Karakteristik dan Pemanfaatan Zeolit Indonesia yang Dilakukan P3TM Periode 1980-1991. Bandung: Pusat Penelitian Pengembangan Teknologi Mineral.

9. Obaje, O. J., Trans-acidolysis process for the preparation of carbohydrate fatty-acid esters, US patent 6846916.

10. Goenadi, D. H., 1993, Proposal Parameter Standar Industri Indonesia untuk Zeolit Alam. Bogor: Pusat Penelitian Bioteknologi Perkebunan.

11. Asep, S., dkk., 1996, Kinetika serapan zeolit terhadap ion sianida. Di dalam: Prosiding Seminar Nasional Kimia II. Jakarta: Fakultas Matematika dan Ilmu Pengetahuan Alam, Universitas Islam Indonesia.

12. Mumpton, F. A., 1984, The Role of Natural Zeolites in Agriculture and Aquaculture. Colorado: West View Press Boulder.

13. Rodrigues, M. G. F., Magnoux, P., \& Guisnet, M., 2000, Influence of hydrothernal treatment on acid and redox function of $\mathrm{Ga} / \mathrm{HZSM} 5$ catalyst, Braz. J.Chem. Eng., 17: 1-6.

14. Muchtar, H., 1983, Penentuan pengaruh perlakuan dengan logam terhadap daya adsorpsi zeolit alam pada pemurnian wax skripsi, Padang: Fakultas Matematika dan Ilmu Pengetahuan Alam, Universitas Andalas.

15. Zulnely, 1985, Study pendahuluan logam mangan dalam air dengan zeolit bayah tesis, Padang: Fakultas Matematika dan Ilmu Pengetahuan Alam, Universitas Andalas. 
